\title{
Comparative Study on the Bacteriological Quality of Kunun-Aya Sold in Wukari, Nigeria
}

\author{
*Alloysius Chibuike Ogodo ${ }^{1}$, Dawn Ify Agwaranze', Chioma Blessing Nwaneri², \\ Michael Nosano Yakubu ${ }^{1}$, Zakariya Jibril Hussaini ${ }^{1}$ \\ ${ }^{1}$ Department of Microbiology, Faculty of Pure and Applied Sciences, Federal University Wukari, P.M.B. 1020 \\ Wukari, Taraba State, Nigeria. \\ ${ }^{2}$ Department of Microbiology, School of Biological Sciences, Federal University of Technology Owerri, Nigeria \\ *Corresponding Author: Alloysius Chibuike Ogodo, Department of Microbiology, Faculty of Pure and \\ Applied Sciences, Federal University Wukari, P.M.B. 1020 Wukari, Taraba State, Nigeria.
}

\begin{abstract}
This study was carried out to ascertain the bacteria quality of kunun-aya from Wukari metropolis. A total of nine (9) samples, three from each of the wards (Avyi, Hospital and Puje) in Wukari and laboratory prepared sample (control) were evaluated for bacterial load and presence of bacteria using standard microbiological techniques. The results show that the $\mathrm{pH}$ of the kunun-aya samples were within the acidic range of 2.03 to 2.16. The total bacterial count ranged from $1.3 \times 10^{7} \mathrm{cfu} / \mathrm{ml}$ to $2.2 \times 10^{7} \mathrm{cfu} / \mathrm{ml}$ while control was $3.0 \times 10^{3} \mathrm{cfu} / \mathrm{ml}$. Total coliform and staphylococcal counts ranged from $1.0 \times 10^{3} \mathrm{cfu} / \mathrm{ml}$ to $7.0 \times 10^{3} \mathrm{cfu} / \mathrm{ml}$ and $4.0 \times 10^{4} \mathrm{cfu} / \mathrm{ml}$ to $8.0 \times 10^{4} \mathrm{cfu} / \mathrm{ml}$ with control having < 10 colonies respectively. Bacteria isolated and their distributions show that Klebsiella species was present in samples AVY1, AVY2, HSP1, HSP2, PUJ2 and PUJ3, Bacillus species was present in samples AVY1, HSP1, HSP2, PUJ2 and control, Staphylococcus aureus was isolated from all the samples except HSP, PUJ2 and control, Citrobacter species, Salmonella species, Shigella species and Micrococcus species were only isolated from samples HSP1, PUJ1, PUJ3 and control respectively, Proteus species was isolated from PUJI and PUJ3, Pseudomonas species was present in $A V Y 3$ and PUJ1, Escherichia coli, was present in AVY1, HSP1, HSP2 and PUJ1 while Enterococcus species was isolated from HSP1, PUJ2 and control. The occurrence of these isolates shows that Staphylococcus aureus was the highest, 7 (70\%), followed by Klebsiella species and Bacillus species having occurrences of 6 (60\%) each, Escherichia coli, 4 (40\%), Enterococcus species, 3 (30\%), Proteus species and Pseudomonas species, $2(20 \%)$ each while Citrobacter species, Salmonella species, Shigella species and Micrococcus species have the least occurrences of 1 (10\%) each. The high bacteria count and the presence of potential pathogenic bacteria in some of the samples is an indication that they were contaminated and this can potentially pose a health hazard to the consumers. Hence, the need for producers and food vendors of kununaya to take hygienic measures in preparation and storage of the product to avoid outbreak of diseases associated with the organisms encountered in this study.
\end{abstract}

Keywords: Kunun-aya, bacterial quality, coliform count, staphylococcal count

\section{INTRODUCTION}

Kunun-aya (tiger-nut milk) is a traditional fermented spicy non-alcoholic tiger-nut beverage that is indigenous and widely consumed in the Northern parts of Nigeria for its nutritional and medicinal properties especially during dry season [1-3]. It is a very refreshing and high nutritive, energy drink produced from tiger nut (Cyperus esculentus). Coconut, pineapple and date fruits may be added to flavour the tiger-nut milk [3]. Locally, kunun-aya is prepared by soaking washed tiger-nuts in water for 2-8 h, grinding the soaked nuts and mixing with water in the ratio of 3 litres of water for $1 \mathrm{~kg}$ of tiger-nuts. The mixture is allowed for a period of time to macerate and then sieved. This is followed by addition of sugar (depending on quantity and taste) and then a final sieving for the pure drink [2, 4]. However, variations exist in procedure depending on taste and cultural habits, leading to differences in organoleptic properties of the milk [5].

Tiger-nut milk is refreshing and have many health benefits. Report indicates that it contributes to the reduction in Low Density Lipoprotein (LDL), and increases, High Density Lipoprotein (HDL) cholesterol $[6,7]$. [8], reported that tiger-nut milk are found to be good in preventing arteriosclerosis, 
and can help prevent heart problems, thrombosis as well as activate blood circulation. Also, tiger-nut milk is suitable for gluten and lactose-intolerant patients as well as individuals with digestion and diarrhea problems due to its ability to provide catalase, lipase, amylase and stimulant which helps in digestion $[7,9,10]$. Tiger nut milk (kunun-aya) is also found to be rich in phosphorus, calcium, magnesium, iron as well as in vitamin $\mathrm{C}$ and $\mathrm{E}$ and free from lactose and gluten [6].

Tiger-nut (Cyperus esculentus) belongs to the family, Cyperaccae, a tuber that grows freely which is widely consumed (raw or fried) in many parts of East and West Africa including Nigeria as source of energy, carbohydrate and protein $[9,11]$. It is rich in vitamins, minerals, digestive enzymes such as amylase, catalase and lipase as well as in phytochemicals and atinutritional factors such as tannins, phytic acids, saponins, glycosides, steroids etc. [3, 8]. However, tiger-nut lack sodium, lactose, gluten and cholesterol, a property that makes it suitable for lactose and gluten intolerance patients as well as hypertensive individuals [3, 7]. Report also indicates that tiger-nut contain higher essential amino acids than those proposed in the protein to satisfy adult needs [12]. Also, tiger nuts are reported to be aphrodisiac and carminative, promoting urine production and menstruation [13].

Kunun-aya has a very short shelf-life at the prevailing weather conditions of tropical Africa and Nigeria and therefore should be consumed within 2-4 hours after production. However, shelf life of the drink can be extended by pasteurization and addition of ginger, garlic and citric acid $[3,14,15]$. Its production in Nigeria has been hampered due to the presence of microorganisms that deteriorate the milk and cause spoilage as a result of unhygienic preparation, use of contaminated raw materials and crude utensils [11, 16]. A range of microorganisms such as Bacillus subtilis, Staphylococcus aureus, Aspergillus flavus, Aspergillus niger, Fusarium solani, Saccharomyces cerevisiae, S. fubiligera and Candida pseudotropicalis have been associated with exposed tiger nut [7, 17]. In a reports by [18] on microbiological safety of tiger-nut in the cape coast metropolis of Ghana, E. coli and Bacillus spp (18.9\%), Enterococcus spp (16.2\%), S. aureus and P. aeruginosa (13.5\%), Streptococcus spp (10.8\%) and Enterobacter cloacae (8.1\%) were isolated. [2], isolated Staphylococcus aureus, E. coli and Streptococcus species from kunun-aya samples. The presence of some of these potential pathogenic organisms in some of the commercial samples could be a matter of serious public health concern. Therefore, the aim of this study is to evaluate the bacteriological quality of commercial kunun-aya sold in Wukari metropolis and compare them to the quality of laboratory prepared sample.

\section{Materials AND Methods}

\section{Sample Collection}

A total of nine (9) freshly prepared samples of kunun-aya were purchased from three (3) wards of Wukari metropolis (Avyi, Puie and Hospital). Three samples were collected from each of these wards. A control sample was also prepared in the laboratory using dry tiger-nuts, which are bought from the market and transported to the Federal University Wukari biology laboratory for analysis.

\section{Preparation of Laboratory-Based Kunun-Aya}

Kunun-aya was prepared in the laboratory following the method described by [19]. Exactly 200g of dry tiger-nuts was weighted using G\&G electronic scale weighing balance (T1000Y, Holland). Foreign materials, bad/cracked nuts and seeds which may alter the taste and quality of the extracted drink were removed. It was then washed with clean water and soaked in $300 \mathrm{ml}$ of Sterile distilled water at room temperature for three (3) days. This was then washed with Sterile distilled water, boiled in $0.2(\mathrm{w} / \mathrm{v})$ solution of sodium bicarbonate for 30 minutes, and dried in Thermostat oven (DHG9101-ISA, U.S.A) at $75^{\circ}$ C. It was then mixed with Sterile distilled water in a 1:4 ratio and milled using electrical grinding machine. The homogeneous slurry sample was filtered using a sieve.

\section{Determination of Bacteria Load and Isolation of bacteria from Kunu-aya}

The bacteria load of the kunun samples were determined following the method of [20] as described by [21]. Serial dilutions of the various kunun-aya samples were made up to $10^{-7}$ with sterile normal saline. $0.1 \mathrm{ml}$ of each dilution was evenly spread on nutrient agar and incubated at $37^{\circ} \mathrm{C}$ for 24 hours. Plates were screened for discrete colonies after incubation period and the actual numbers of bacteria (total bacteria count) were estimated as colony forming unit per $\mathrm{ml}(\mathrm{cfu} / \mathrm{ml})$ of the sample. Total coliform count (TCC) and total staphylococcal count (TSC) were performed in similar manner using Mac Conkey agar and Mannitol Salt Agar (MSA) mediums respectively. In each case plating was 
done in triplicates and counts taken from plates that had less than 300 colonies. Bacteria load was estimated using standard method of the International Commission on Microbiology Specification for Food (ICMSF) [22]. The colonies were examined closely and distinct colonies were taken and subcultured in fresh sterile medium and incubated at $37^{\circ} \mathrm{C}$ for $24 \mathrm{~h}$ to obtain pure cultures. The pure cultures were characterized and identified as previously described by [23], and [24] with reference to [25].

\section{RESUlts}

Table 1 presented the $\mathrm{pH}$ of the kunun-aya samples. The result showed that all the samples were within the acidic range with sample AVY2 having the highest value (2.16) and sample PUJ3 having the lowest value (2.03) while the laboratory control sample showed the value of (2.04).

The enumeration of the organisms in the various samples showed that the total bacterial count was observed to be highest in sample AVY1 $\left(2.0 \times 10^{8} \mathrm{cfu} / \mathrm{ml}\right)$, followed by sample HSP2 $\left(2.2 \times 10^{7}\right.$ $\mathrm{cfu} / \mathrm{ml})$, HSP1 $\left(2.1 \times 10^{7} \mathrm{cfu} / \mathrm{ml}\right)$, PUJ2 $\left(1.9 \times 10^{7} \mathrm{cfu} / \mathrm{ml}\right)$, AVY3, PUJ1 and PUJ3 having $\left(1.5 \times 10^{7}\right.$ cfu/ml) each. Sample AVY2 and HSP3 showed a count of $1.3 \times 10^{7} \mathrm{cfu} / \mathrm{ml}$ and $1.2 \times 10^{7} \mathrm{cfu} / \mathrm{ml}$ respectively, while the laboratory prepared sample presented the least count of $3.0 \times 10^{3} \mathrm{cfu} / \mathrm{ml}$. The total coliform count ranged from $1.0 \times 10^{3}$ to $7.0 \times 10^{3} \mathrm{cfu} / \mathrm{ml}$ with control having $<10$ colonies while the staphylococcal count ranged from $4.0 \times 10^{4}$ to $8.0 \times 10^{4} \mathrm{cfu} / \mathrm{ml}$ and $<10$ colonies in control (Table 2).

Table 3 presents the bacteria isolated from the various samples and their distributions. The result shows that Klebsiella species was present in samples AVY1, AVY2, HSP1, HSP2, PUJ2 and PUJ3, Bacillus species was present in samples AVY1, HSP1, HSP2, PUJ2 and control, Staphylococcus aureus was isolated from all the samples except PUJ2 and control, Citrobacter species, Salmonella species, Shigella species and Micrococcus species were only isolated from samples HSP1, PUJ1, PUJ3 and control respectively, Proteus species was isolated from PUJ1 and PUJ3, Pseudomonas species was present in AVY3 and PUJ1, Escherichia coli, was present in AVY1, HSP1, HSP2 and PUJ1 while Enterococcus species was isolated from HSP1, PUJ2 and control.

Table 4 showed the percentage occurrence of the isolates. The result showed that Staphylococcus aureus was the highest, 7(70\%), followed by Klebsiella species and Bacillus species having occurrence, 6 (60\%), Escherichia coli, 4 (40\%), Enterococcus species, 2 (20\%) and Proteus species and Pseudomonas species, 2 (20\%) while Citrobacter species, Salmonella species, Shigella species and Micrococcus species having the least value, $1(10 \%)$.

Table 1. $p H$ values of kunun-aya samples.

\begin{tabular}{|l|c|c|}
\hline S/N & Samples & pH \\
\hline 1 & AVY1 & 2.05 \\
\hline 2 & AVY2 & 2.16 \\
\hline 3 & AVY3 & 2.10 \\
\hline 4 & HSP1 & 2.09 \\
\hline 5 & HSP2 & 2.07 \\
\hline 6 & HSP3 & 2.09 \\
\hline 7 & PUJ1 & 2.04 \\
\hline 8 & PUJ2 & 2.11 \\
\hline 9 & PUJ3 & 2.03 \\
\hline 10 & CTL & 2.04 \\
\hline
\end{tabular}

AVY1-3=Avyi ward samples, HSP1-3=Hospital ward samples, PUJ1-3=Puje ward samples, CTL= control.

Table 2. Bacterial load of kunun-aya samples

\begin{tabular}{|l|c|c|c|c|}
\hline S/N & Samples & $\begin{array}{c}\text { Total bacterial count } \\
(\mathbf{c f u} / \mathbf{m l})\end{array}$ & $\begin{array}{c}\text { Total coliform count } \\
(\mathbf{c f u} / \mathbf{m l})\end{array}$ & $\begin{array}{c}\text { Total staphylococcal count } \\
\text { (cfu/ml) }\end{array}$ \\
\hline 1 & AVY1 & $2.0 \times 10^{7}$ & $1.1 \times 10^{3}$ & $8.0 \times 10^{4}$ \\
\hline 2 & AVY2 & $1.2 \times 10^{7}$ & $5.0 \times 10^{3}$ & $5.0 \times 10^{4}$ \\
\hline 3 & AVY3 & $1.5 \times 10^{7}$ & $6.0 \times 10^{3}$ & $5.0 \times 10^{4}$ \\
\hline 4 & HSP1 & $2.1 \times 10^{7}$ & $4.1 \times 10^{3}$ & $7.0 \times 10^{4}$ \\
\hline 5 & HSP2 & $2.2 \times 10^{7}$ & $7.0 \times 10^{3}$ & $6.0 \times 10^{4}$ \\
\hline 6 & HSP3 & $1.3 \times 10^{7}$ & $4.0 \times 10^{3}$ & $6.0 \times 10^{4}$ \\
\hline 7 & PUJ1 & $1.5 \times 10^{7}$ & $1.0 \times 10^{3}$ & $5.0 \times 10^{4}$ \\
\hline 8 & PUJ2 & $1.9 \times 10^{7}$ & $6.0 \times 10^{3}$ & $4.0 \times 10^{4}$ \\
\hline 9 & PUJ3 & $1.5 \times 10^{7}$ & $5.0 \times 10^{3}$ & $<10$ \\
\hline 10 & CTL & $3.0 \times 10^{3}$ & $<10$ & $\mathrm{CT}$ \\
\hline
\end{tabular}

AVY1-3=Avyi ward samples, HSP1-3=Hospital ward samples, PUJ1-3=Puje ward samples, CTL= control. 
Table 3. Distribution of the Isolates in the Samples

\begin{tabular}{|l|c|c|c|c|c|c|c|c|c|c|}
\hline Samples & AVY1 & AVY2 & AVY3 & HSP1 & HSP2 & HSP3 & PUJ1 & PUJ2 & PUJ3 & CTL \\
\hline Klebsiella species & + & + & - & + & + & - & - & + & + & - \\
\hline Bacillus species & + & - & - & + & + & + & - & + & - & + \\
\hline $\begin{array}{l}\text { Staphylococcus } \\
\text { aureus }\end{array}$ & + & + & + & - & + & + & + & - & + & - \\
\hline Citrobacter species & - & - & - & + & - & - & - & - & - & - \\
\hline Salmonella species & - & - & - & - & - & - & + & - & - & - \\
\hline Proteus species & - & - & - & - & - & - & + & - & + & - \\
\hline Escherichia coli & + & - & - & + & + & - & + & - & - & - \\
\hline Pseudomonas species & - & - & + & - & - & - & + & - & - & - \\
\hline Shigella species & - & - & - & - & - & - & - & - & + & - \\
\hline Micrococcus species & - & - & - & - & - & - & - & - & - & + \\
\hline Enterococcus species & - & - & - & + & - & - & - & + & - & - \\
\hline
\end{tabular}

AVY1-3=Avyi ward samples, HSP1-3=Hospital ward samples, PUJ1-3=Puje ward samples, CTL= control.

Table 4. Percentage occurrence of the isolates in the samples.

\begin{tabular}{|l|c|c|}
\hline Organisms & Frequency & Percentage (\%) \\
\hline Klebsiella species & 6 & 60 \\
\hline Bacillus species & 6 & 60 \\
\hline Staphylococcus aureus & 7 & 70 \\
\hline Citrobacter species & 1 & 10 \\
\hline Salmonella species & 1 & 10 \\
\hline Proteus species & 2 & 20 \\
\hline Escherichia coli & 4 & 40 \\
\hline Pseudomonas species & 2 & 20 \\
\hline Shigella species & 1 & 10 \\
\hline Micrococcus species & 1 & 10 \\
\hline Enterococcus species & 2 & 20 \\
\hline
\end{tabular}

\section{DISCUSSION}

In the present study, all the samples were found to be within the acidic $\mathrm{pH}$ range of 2.03 to 2.16 . Similar observations have been reported by previous researchers $[2,14,26,27]$ and are attributed to the presence of certain species of lactic acid bacteria leading to production of lactic acid during the fermentation processes. However, the $\mathrm{pH}$ range observed in this study is lower than the report of [28] and [29] who reported 3.0-3.14 and 5.50 respectively for locally produced kunun-aya. Also, [30] reported $\mathrm{pH}$ range of 2.64-5.0 in kunun-zaki. The low $\mathrm{pH}$ values observed in the study is desirable as reports have shown that low $\mathrm{pH}$ values give advantage to fermentative organisms over spoilage organisms [31].

The present study revealed that most of the samples purchased contained high bacterial count ranging from $3.0 \times 10^{3} \mathrm{cfu} / \mathrm{ml}$ (control) to $2.2 \times 10^{7} \mathrm{cfu} / \mathrm{ml}$ (HSP2) which is in agreement with the findings of [30] who reported bacterial count ranging between $5.1 \times 10^{3} \mathrm{cfu} / \mathrm{ml}$ to $2.0 \times 10^{8} \mathrm{cfu} / \mathrm{ml}$ in kunun-zaki sample. Similarly, [32] and [33] reported a total bacterial count ranging from $5.0 \times 10^{4} \mathrm{cfu} / \mathrm{ml}$ to $2.0 \times$ $10^{6} \mathrm{cfu} / \mathrm{ml}$ and $1.0 \times 10^{2} \mathrm{cfu} / \mathrm{ml}$ to $8.9 \times 10^{4} \mathrm{cfu} / \mathrm{ml}$ respectively in kunun-zaki. Also, [34] reported a relatively high count bacterial load of $2.3 \times 10^{8} \mathrm{cfu} / \mathrm{ml}$ in kunun-aya sample. The coliform count and staphylococcal counts in the present study ranged from $<10$ colonies to $7.0 \times 10^{3} \mathrm{cfu} / \mathrm{ml}$ and $<10$ colonies to $8.0 \times 10^{4} \mathrm{cfu} / \mathrm{ml}$ respectively. The high bacterial count observed in the commercial samples could be attributed to environmental factors (exposure of the samples to soil, air etc.), type of water used in processing as well as personal hygiene of the handlers $[35,36]$. It could also be due to microorganisms inherent to the tiger-nut from which the kunun-aya was obtained which later multiply, milling method and milling machine [37, 38]. The low counts observed in the laboratory prepared kunun-aya is an indication that it was aseptically and hygienically prepared and shows a mark of quality product.

In the present study, the bacteria isolated from the commercial and laboratory prepared kunun-aya are Klebsiella species, Bacillus species, Staphylococcus aureus, Citrobacter species, Salmonella species, Proteus species, Escherichia coli, Pseudomonas species, Shigella species, Micrococcus species and Enterococcus species. Similar organisms have been reported on kunun-zaki samples [30, 39]. Also, 
[2] isolated, Staphylococcus aureus, E. coli and Strptococcus species from kunun-aya samples. The presence of some of these potential pathogenic organisms in some of the commercial samples could be a matter of serious public health concern. Bacillus species and Staphylococcus aureus are common contaminants of food especially from food handlers, environment and post process contaminations [21]. Moreover, S. aureus is a normal flora of the skin, nose, mucus membrane etc. and is implicated as cause of septic arthritis [34]. Also, Staphylococcus aureus and Bacillus causes staphylococcal and Bacillus food borne intoxication respectively. Some strains of Escherichia coli such as EHEC causes haemorrhegic diarrhea which can result to serious health conditions as kidney failure and even death. Salmonella and Shigella species cause salmonellosis and shigellosis when consumed through food [40-43]. Moreover, according to the report of [44] on kunun-aya, the presence of Bacillus cereus, $S$. aureus and $E$. coli in beverages can render them unsuitable for human consumption and as well serve as a medium of disease transmission. Contamination of commercial kunun-aya samples with these organisms could have occurred from water and equipment during processing and storage or through the handlers or from the environment as a result of poor sanitation and hygiene. Also, these organisms when present in food causes spoilage and this could account for the short shelf of kunun-aya [45].

In the present study, the occurrences of the isolates showed that Staphylococcus aureus was the highest, 7 (70\%), followed by Klebsiella species and Bacillus species having occurrence, 6 (60\%), Escherichia coli, 4 (40\%), Enterococcus species, 2 (20\%) and Proteus species and Pseudomonas species, $2(20 \%)$ while Citrobacter species, Salmonella species, Shigella species and Micrococcus species having the least value, $1(10 \%)$. This observation is comparable to the report of [39] who reported 72\% (S. aureus), 60\% (E. coli), 56\% (Bacillus species) and 28\% for Salmonella spp. from kunun-zaki. The high rate of $S$. aureus $(70 \%)$ and Bacillus species (60\%) is of public health concern because the organisms are implicated as causes of food borne intoxication [43]. The high occurrence of Klebsiella species (60\%), E. coli (40\%) and Enterococcus species (20\%) is an indication of feacal contamination. Hence, the need for hygienic measures to be taken during processing of the drink.

\section{CONCLUSiON}

The present study has shown that commercial kunun-aya samples under study have high bacteria load. It has also shown that most of the samples were contaminated with potentially pathogenic microorganisms which are of public health importance. Hence, the need to employs standard hygienic measures during preparation and storage of kunun-aya, to avoid outbreak of diseases associated with some of the organisms isolated in this study.

\section{REFERENCES}

[1] T.S. Okafor, E. Nwachukwu, Phytochemical screening of Tiger-nut (Cyperus esculentus) of three different varieties. J. Biol. Sci. 81 (2003) 115-120.

[2] A.A. Musa, A. Hamza, Comparative analysis of locally prepared "kununaya" (Tiger nut milk) consumed by students of Kaduna state university, Kaduna, Nigeria. Sci. World J. 8 (2013) 13-18.

[3] R.M. Kayode, J.K. Joseph, M.O. Adegunwa, A.O. Dauda, S.A. Akeem, B.I. Kayode, A.A. Babayeju, S.O. Olabanji, Effects of Addition of Different Spices on The Quality Attributes of Tiger-Nut Milk (Kunun-Aya) During Storage. J. Microbiol. Biotechnol. Food Sci. 7 (1) (2017) 1-6.

[4] J.A. Ayo, J.C. Okaka, Interaction Effect of CadabaFarinose extract and pH Levels on Some Physiological Properties of Kunun-Zaki (1998) Pp 31 - 33. Proc. of the 22nd Ann. NIFST Conf. 23rd - 26th November, Abeokuta Nigeria.

[5] T. Adeyemi, S. Umar, Effect of manufacture of the quality characteristics of kununzaki, a millet based beverage: Niger. Food J. 12 (1994) 34-40.

[6] M.A. Belewu, O.A. Abodunrin, Preparation of Kunnu from unexploited rich food source: Tiger Nut (Cyperus esculentus). World J. Dairy Food Sci. 1 (2006) 19- 21.

[7] A. Gambo, A. Da'u, Tiger nut (Cyperus esculentus): composition, products, uses and health benefits - a review. Bayero J. Pure Appl. Sci. 7 (1) (2014) 56 - 61.

[8] E. R. Chukwuma, N. Obiama, O.I. Christopher, The phytochemical composition and some biochemical effect of Nigerian tiger-nut (Cyperrus esculentus) tuber. Pak. J. Nutr. 9 (7) (2010) 709-715.

[9] R. Abaejoh, I. Djomdi, R. Ndjouenkeu, Characteristics of Tigernut (Cyperus esculentus) tubers and their performance in the production of a milky drink. J. Food Process. Preserv, 30: 145-163.

[10] J.A. Adejuyitan, Tiger-nut processing: Its food uses and health benefit. Am. J. Food Technol. 6 (3) (2011) 197-201. 
[11] Z.D. Umar, A. Bashir, S.A. Raubilu, Study On Bacteriological Quality Of KununAya (Tigernut Juice) Sold At Umaru Musa Yar'adua University (Umyu) Campus, Katsina. Inter. J. Environ. 3 (2) (2014) 87-97.

[12] L. Bosch, A. Alegría, R. Farré, RP-HPLC determination of tiger nut and orgeat amino acid contents. Food Sci. Technol. Inter., 11 (1) (2005) 33-40.

[13] Wills, J.B. (1962). Tiger nut (Cyperus esculentus). Agriculture and land use in Ghana. London: Oxford University press for Ghana Ministry of food and Agric. P 504.

[14] O. Akoma, E.A. Jiya, D.D. Akumka, E. Mshelia, Influence of malting on the nutritional characteristics of Kunun-Zaki. Afri. J. Biotechnol. 10 (5) (2006) 996-1000.

[15] P.N.U. Nwobosi, N.R. Isu, O.O. Agarr, Influence of pasteurization and use of natural tropical preservatives on the quality attributes of tiger nut drink during storage. Inter. J. Food Nutr. Sci. 2 (2013) 27-32.

[16] B. Osuntogun, O.O. Abiola, Microbiological and evaluation of some non-alcoholic beverages. Pak. J. Nutr. 3 (2004) 188-192.

[17] J.C. Onovo, A.O. Ogaraku, Studies on some Microorganisms Associated with exposed tigernut (Cyperusesculentus L.) Milk. J. Biol. Sci. 7 (8) 1548-1550.

[18] D.N. Hubert, N.A.T. Daniel, A. Yaw, Assessment of microbiological safety of tjger-nuts (Cyperrus esculentus) in the cape coast metropolis of Ghana. Archives of Appl. Sci. Res. 3 (6) (2011) 257-262.

[19] L.O. Udeozor, S.O. Awonorin, Comparative microbial analysis and storage of tigernut-soy milk extract. Austin J.Nutr.Food Sci. 2 (5) (2014) 1026.

[20] N. Rashed, U. Md. Aftab, H. Md. Azizul, K.M. Saurab, A. Mrityunjoy, M.R.Majibur, Microbiological study of vendor and packed fruit juices locally available in Dhaka city, Bangladesh. Inter. Food Res. J. 20 (2) (2013) 1011-1015.

[21] A.C. Ogodo, O.C. Ugbogu, U.G. Ekeleme, N.O. Nwachukwu, Microbial Quality of Commercially Packed Fruit Juices in South-East Nigeria. J. Basic Appl. Res. 2 (3) (2016) 240-245.

[22] ICMSF (International Commission on Microbiology Specification for Food) Microorganisms in Foods. Micr. Ecol. Food Commod. 6 (1998) 615-616.

[23] M.O. Fawole, B.A. Oso, Laboratory Manual of Microbiology. Spectrum Books Limited, Ibadan, (1988) pp 21-24.

[24] S.T. Cowan, K.T. Steel, Manual for the Identification of Medical Bacteria. 2nd edition. Cambridge University Press, London, (1975) pp 22-122

[25] J.G. Holt, N.R. Krieg, P.H. Sneath, J.T. Staley, S.T. Williams, Bergey's Manual of Determinative Bacteriology. 9th edition. Williams and Wilkins, Baltimore (1994) pp 650-851.

[26] B.J.O. Efiuvwevwere, O. Akoma, The Microbiology of KunuZaki. A Cereal Beverage from Northern Nigeria during the Fermentation (Production) Process. World J. Microbiol. Biotechnol. 11 (1995) 491- 493.

[27] C.E.Oshoma, M.O.Aghimien, Z.O. Bello, (2009). Growth and Survival of Escherichia coli in kunun during storage. World J. Agri. Sci. 5 (4) 494-497.

[28] J.A. Ayo, G. Umaianze, T. Gaffa, Microbiological evaluation of kununaya and Zoborodo drink (beverage) locally produced and sold in a polytechnic community in Nigeria. Niger. Food J. 22 (2004) 189-7241.

[29] M.A. Belewu, O. A. Abodunrin, Preparation of Kunun from unexploited rich food source: Tiger nut (Cyperus esculentus). Pak. J. Nutr. 7 (1) (2008) 109-111.

[30] M.I. Aboh, P. Oladosu, Microbiological assessment of Kunun-aya marketed in Abuja municipal area council (AMAC) in federal capital territory (FCT), Nigeria. Afri. J. Microbiol. Res. 8 (15) (2014) 16331637.

[31] A.C. Ogodo, O.C. Ugbogu, A.E. Ugbogu, C.S. Ezeonu, Production of mixed fruit (pawpaw, banana and watermelon) wine using Saccharomyces cerevisiae isolated from palm wine. SpringerPlus (2015), 4: (2015a) 683. DOI: 10.1186/s40064-015-1475-8.

[32] A.M. Elmamood, J.H. Doughari, Microbial quality of kunun beverage sold in Girei town of Adamawa State, Nigeria. Afri. J. Food Sci. (2007) 11-15

[33] A.O. Lawal, Microbial quality of kunun beverage sold in Ile-ife, Osun State. J. Food Technol. 10 (1) (2012) 4-7.

[34] A.A. Taiwo, J.A. Ademoyegun, T. Ijaola, O.A. Lawal, Comparative study of nutritive composition and microbial level of Kunun sold in three campuses in Abeokuta. Sky J. Food Sci. 6 (1) (2017) 007-013.

[35] A.H. Kawo, F.N. Abdulmumin, Microbiological quality of prepackaged sweets sold in metropolitan Kano, Nigeria. Bayero J. Pure Appl. Sci. 2 (1) (2009) 154-159.

[36] A. Bukar, M. Yushau, E.M. Adikwu, Incidence and identification of potential pathogens on hands of some personnel in some small - scale food industries in Kano Metropolis. Nigeria. Biol. Environ. Sci. J. Trop. 6 (2009) 4 . 
[37] S.A. Batool, N. Rauf, S.S. Tahir, R. Kalsoom, Microbial and physic-chemical contamination in the wheat flour of the twin cities of Pakistan. Inter. J. Food Safety, 14 (2012) 75-82.

[38] A.C. Ogodo, O.C. Ugbogu, U.G. Ekeleme, Bacteriological quality of commercially prepared fermented Ogi (akamu) sold in some parts of South-eastern Nigeria. Inter. J. Biol, Biomol. Agri. Food Biotechnol. Eng. 9 (6) (2015b) 649-652.

[39] S.D. Gyar, H. Bala, C.R. Reuben, Bacteriological Quality Assessment of Nigerian Non Alcoholic Beverage (Kunun-zaki) Sold in Keffi Metropolis, Nigeria. Greener J. Microbiol. Antimicr. 2 (2) (2014) 021-025.

[40] B. Ray, Fundamental food microbiology, 3rd edition. CRC Press, New York (2004).

[41] M.N. Indu, A.A. Hatha, C. Abinosh, U. Harsha, G. Vivekanandan, Antimicrobial activity of some South Indian spices against serotypes of Escherichia coli, Samonella, Listeria monocytogenesand Aeromonashydrophila. Braz. J. Microbiol. 37 (2006) 153 - 158.

[42] WHO (2007). Foodborne Disease Outbreak Guidelines. www.who.int/foodsafety/publications/foodborne_ disease/FERG_Nov07pdf. Date accessed, November, 3, 2017.

[43] A.C. Ogodo, D.I. Agwaranze, C.B. Nwaneri, U.C. Okoronkwo, U.G. Ekeleme, Activity of Leave and Stem Bark Cuttings of Ocimum gratissimum Extracts on Foodborne Pathogens. AASCIT J. Biosci. 3 (2) (2017) 5-11.

[44] A.A. Adesiyun, J. Adekeye, O. Umoh, J.U. Nadaraga, Bacteriology of Cereals. J. Hyg. 90 (1983) 195 205.

[45] I.F. Bolarinwa, J.A. Adejuyitan, E.T. Otunola, E.A. Akande, F.M. Oladukun, Some physiochemical properties obtained from fermentation of local beverages. Afri. J. Food Sci. 3 (2009) 21-27.

Citation: A. C. Ogodo et al., "Comparative Study on the Bacteriological Quality of Kunun-Aya Sold in Wukari, Nigeria ", International Journal of Research studies in Microbiology and Biotechnology, vol. 4, no. 1, p. 23-29, 2018. http://dx.doi.org/10.20431/2454-9428.0401004

Copyright: (C) 2018 Authors. This is an open-access article distributed under the terms of the Creative Commons Attribution License, which permits unrestricted use, distribution, and reproduction in any medium, provided the original author and source are credited. 